Florida International University

FIU Digital Commons

$4-19-1983$

\title{
Is there discrimination against female reservation managers of hotels and motels along the ocean side of Collins Avenue?
}

\author{
Miriam D. Goldberg \\ Florida International University
}

Follow this and additional works at: https://digitalcommons.fiu.edu/etd

Part of the Hospitality Administration and Management Commons

\section{Recommended Citation}

Goldberg, Miriam D., "Is there discrimination against female reservation managers of hotels and motels along the ocean side of Collins Avenue?" (1983). FIU Electronic Theses and Dissertations. 3945.

https://digitalcommons.fiu.edu/etd/3945

This work is brought to you for free and open access by the University Graduate School at FIU Digital Commons. It has been accepted for inclusion in FIU Electronic Theses and Dissertations by an authorized administrator of FIU Digital Commons. For more information, please contact dcc@fiu.edu. 
IS THERE DISCRIMINATION AGAINST FEMALE RESERVATION MANAGERS OF HOTELS AND MOTELS ALONG THE OCEAN SIDE OF COLLINS AVENUE?

A Dissertation Presented to The Faculty of the School of Hospitality Management

Florida International University

In Partial Fulfillment of the Requirements

For The Degree of Master of Science

Miriam D. Goldberg

April, 1983 
This thesis having been approved in respect to form and mechanical execution is referred to you for judgment upon its substantial merit.

\author{
DEAN ANTHONY G. MARSHALL \\ SCHOOL OF HOSPITALITY MANAGEMENT
}

The Thesis of Miriam D. Goldberg is approved.

PROFESSOR CHARLES ILVENTO

SCHOOL OF HOSPITALITY MANAGEMENT

PROFESSOR DONALD GREENAWAY
SCHOOL OF HOSPITALITY MANAGEMENT

Date of Examination: April 19, 1983 


\section{Abstract}

Since the beginning of time, men and women have been separated by the "division of labor." Men were hunters and defenders and the women nurturers, bearing the responsibility of the raising of the children and homemaking.

By the time of the Greeks, women were afforded great respect and treated with great dignity. They were looked upon as the pillars of morality and tradition.

In 1765, women had been legally declared non-persons in William Blackstone's Commentaries on English Law. Further reinforcement of this belief was put forth by Max Weber and Sigmund Freud who both felt women had no place in organizations and business.

Women wanted recognition of their "personhood" and from the first women's rights convention in 1848, demanding and finally obtaining the vote in 1920, through to the Civil Rights Movement in the 60 's and the women's movement which grew out of it, women have been making strong statements for equality and job opportunities.

Just how successful women have been in their demands for acceptance in the business world is examined in this dissertation. 


\section{Acknowledgements}

The author wishes to thank her family for all their patience, love, understanding, and cooperation during all these years of school. Also, thanks especially to Joyce K. Julien, M.S., R.D., whose friendship, patience, intelligence, and determination have always been inspirational.

Thank you Professor Ilvento, for all your assistance on this project, and also to Dean Marshall. Thank you, too, all those women working in the hotels and motels on Miami Beach for being so cooperative. 
Page

Abstract . . . . . . . . . . . . . i $i$

Acknowledgements . . . . . . . . . . . . ii

Chapter 1: The Nature and Scope of the Study. . I

Reservations Managers . . . . . . . . 2

Assumption One . . . . . . . . . 3

Assumption Two ............. . 3

The Research Methodology ......... 4

Chapter 2: The Review of the Related

Literature . . . . . . . . . 6

Psychology . . . . . . . . . . 12

Politics . . . . . . . . . . 15

Statistics . . . . . . . . . . 21

Review of Women in Management in

Hospitality . . . . . . . . . . 24

The Forecast for the Future . . . . . . 29

Chapter 3: State of the Lodging Industry

and Future Trends ......... . . 31

Chapter 4: Findings, Discussion and Conclusion. 36

Discussion . . . . . . . . . 39

Bibliography . . . . . . . . . . 41

Appendix . . . . . . . . . . . . 44 44

Vita ................. 56 


\section{Chapter 1: The Nature and Scope of the Study}

This research proposes to ascertain whether or not women presently in managerial positions in the Hospitality Industry in the Miami Beach area feel they are afforded the same equities as men with regard to responsibilities, income, promotions, and benefits. Men might have the same insecurities as women, but this researcher is only looking at women in these managerial positions and their perceptions at the present time. The point is, the women who are not there may be complaining that women are not always given the opportunities for leadership and decision-making. This paper will attempt to present the opinion of women in managerial positions.

More and more married women are joining the work force because very often a single paycheck cannot cover expenses during these inflationary times. Also, a woman may find herself the sole support of her family and must earn a wage comparable to that of a man's. Or, a woman may decide to work because her children are grown and she needs to keep herself busy and contribute her skills to the work force.

Whatever the reason, any woman wishing to obtain a job should be able to do so and have the same benefits, responsibilities, and financial remuneration as a man holding the same position. 
The researcher is proposing that women are not treated in a manner consistent with the treatment afforded men in reservation management positions in the Hospitality Industry in the Miami Beach area.

For the purpose of this study, the following definitions and assumptions are significant:

Reservation Managers

The first responsibility is to control and monitor the sale of room rights and to maximize the rate efficiency through tier pricing and aggressive selling through the reservations. Reservation clerks are directly responsible to managers. Managers must monitor clerks for accuracy and neatness. They must be aware of operating costs and control unnecessary overtime. In addition, they must insure that all employee evaluations are done fairly and in a professional manner. They supervise preblocking of all larger groups. They personally insure proper handling of all Very Important Persons (VIPs), and special requests by the general manager. They insure development of reservations clerks and new people hired by the front desk. They authorize all sold-out dates and construct all forecasting. ${ }^{1}$

$I_{\text {Marriott Hotels, Inc. Job Description for Reserva- }}$ tions Managers. 
In addition, reservation managers are further defined as such under the Fair Labor Standards Act of the Wage and Hour Division of the United States Department of Labor. The six points under which they qualify for exemption from minimum wage and overtime requirements are as follows:

1. Management is their primary responsibility,

2. They supervise two or more employees,

3. They are able to hire and fire employees or recommend such actions,

4. They exercise independent judgement and discretion,

5. They do not devote as much as 40 percent of their time performing routine or clerical tasks during the work week, and,

6. They receive a salary of One Hundred and FiftyFive Dollars per week. ${ }^{2}$

Assumption One

Women are making important contributions as members of the work force.

Assumption Two

Women are not treated equitably in the managerial positions they hold in the major hotels and motels along the ocean side of Collins Avenue.

2U.S. Department of Labor, Employment Standard Administration, Wage and Hour Divisions. Executive, Administrative, Professional and Outside Sales Exemptions Under Fair Labor Standards Act. Publication 1363, August, 1976. 
There are two types of data utilized in this report. They are primary and secondary:

The primary data. This consists of the questions submitted to and the answers given by the various reservation managers of the hotels and motels.

The secondary data. This consists of a review of the available literature and other pertinent information to be found in newspapers, periodicals, and government publications.

The Research Methodology

The survey method for collecting data is to be used in this study. Item analysis is to be used in making the decision necessary to either prove or disprove the hypothesis.

The data needed are the answers to the questionnaires prepared in advance and submitted spontaneously to female reservation managers of the aforementioned hotels and motels. All interviews will have taken place in person in the various hotels along the ocean side of Collins Avenue. The original intention was to confine the investigation to the major hotels, but because of the current economic situation, there are too few hotel sites to make a satisfactory research project and thus, motels were included. 
The interviewees will not have known ahead of time that the questions were going to be posed to them and they will have had to give spontaneous answers without preplanning.

The questionnaire has been prepared and is attached. The survey will have been conducted in person in each of the hotels and motels determined beforehand.

The data will be evaluated by tallying each answer. Each question will be evaluated as to a "yes" or "no" response and the resulting figures put into percentages. A chart showing comparisons will be included.

The various hotels and motels will be noted as to whether they are chain owned or privately owned and the appropriate percentages also presented in chart form. From the computations it will be possible to conclude if the original hypothesis is correct. 


\section{Chapter 2: The Review of the Related Literature}

Why is there such vast inequality of salaries, status, and responsibilities at management levels? The first level of explanation must emphasize economic competition for precious resources and the monopolization of privilege by white males. In addition, however, there are other barriers. Let us take an historical view of women from the earliest known times.

All human societies have established some sort of division of labor on the basis of sex. The pattern in many prehistoric foraging societies (hunters and gatherers) was for the men to hunt and for the women to collect, but the specific tasks allotted to each sex depended on the environment and the traditions that the human population developed for dealing with it. Women gathered vegetation, insects, slow-moving game, some marine and fresh-water fauna, while the men hunted, collected, and fished for larger species. ${ }^{3}$

There is evidence which shows that during the time of Cro-Magnon Man, dating about 15,000 to 10,000 B.C., women played a subordinate role. However, they were not entirely dependent on men for survival since the aforementioned gathering of fruits, roots, and berries fell to them. Also,

${ }^{3}$ C. Kottak, Cultural Anthropology, Random House, New York, 1975. 
if the tribes did not depend on the migration of animals for food, it was possible for the people to settle down in one place for considerable periods of time and have a house. Homemaking was, of course, woman's work; this concept taking hold early on as the men went hunting for the fresh meats and the women stayed behind to give birth, tend to the children, and prepare the foods. 4

Cro-Magnon artists have also left us with tiny statuettes of women, only a few inches high, made of stone, bone, ivory, clay, and ground bone, which have been fired. These depict female figures with greatly exaggerated breasts, buttocks, and stomach. The speculation is that they were tiny earth goddesses or fertility figures. This was a time of strong male domination in society. Women played a subordinate role. ${ }^{5}$ But, these figures depict woman as being respected for what they were--the bearers of children and the nurturers of the family.

By the time of Greek civilization, the belief was that women were the goal and ideal of erotic admiration. In addition, they also had a constant social and legal status as mistress of the household, and as such their

${ }^{4}$ Life Nature Library, Early Man, New York, 1972. ${ }^{5}$ Ibid.

${ }^{6}$ Ibid. 
virtues were sober morality and domestic prudence. ${ }^{7}$ Women held a higher social position at the close of the period of Homeric chivalry than at any other time in Greek history. The respect and honor paid to a woman was not merely due to the useful work she did nor to her position as mother of legitimate children to carry on the name, but also Homeric nobility which honored women as the respositories of high morality and old traditions. 8

In Plato's Republic, the idea was put forth that women should be trained to be guards. Plato was opposed to the prevailing view that women were meant, by nature, only to bear children, bring them up, and look after the household. Plato admitted that women were generally less strong than men, but did not think that that should prevent them doing their share of guard duties. So, if they did the same work, they should have the same upbringing and education. Therefore, the women of the ruling class were to be schooled in music and gymnastics just like the men and also be trained for war. 9

But, by admitting women to men's vocation, didn't plato contradict his own principle that justice in an

${ }^{7}$ W. Jaeger, Paideia: The Ideals of Greek Culture, Vol. I, Oxford Press, New York, 1943.

8 Ibid.

${ }^{9}$ Ibid. 
organic state meant that everyone performed his own natural function? ? $^{10}$ The point of it is that those who are differently equipped by nature should do different jobs. No doubt the natural difference between men and women exists, but they still may be equally well equipped for the same vocation. Man's superiority means that he is better than woman in every sphere, even in those which are declared to be woman's province by those who maintain she is a domestic creature: cookery, baking, and weaving, but there is no one work which man or woman alone can do and which is impossible for the other sex. ${ }^{11}$

Therefore, the training of women in music and gymnastics was not contrary to nature. The existing situation is against nature, for it makes it impossible for woman to develop her natural gifts. This was a logical result of a process which began in the age of Pericles and Euripedes. In early Athens women were neither physically nor mentally trained. They were confined to the house. Since then they had evidently been taking more and more part in the intellectual life of the day, and particularly in its educational interests. The increasing number of great female characters

${ }^{10}$ E. Barker, Plato's Republic and Greek Political Theory, London, 1925.

${ }^{11_{W}}$. Jaeger, Paideia: The Ideals of Greek Culture, Vol. II, Oxford press, New York, 1943. 
in tragedy show that woman had been discovered to be a human being and her right to education was publicly discussed. ${ }^{12}$ Another description of the role of women was written by Xenophon who lived during the same time as Plato (4th Century, B.C.). Xenophon believed in education also, but was concerned more with the rural aspect of Grecian life and set down the standards for the ideal farmer and his wife. Xenophon believed that a farmer's chief duty was to teach his household and the most important pupil was his wife. He described her as the personage of chief interest in the farm, the queen bee of the hive. ${ }^{13}$

The passive wife of a townsman, who, with her servants went through the same daily round of household tasks, spending her leisure on clothes, making up her face and exchanging gossip would have been useless in a big farmhouse. Xenophon portrayed the wife of a farmer as her husband's true helper. She was the mistress of the household, while her husband directed the laborers in the field. He was responsible for everything coming into the house and she was in charge of storing and using it. She had to bring up and educate the children. She was responsible for the cellar and the kitchen and arranged the baking and the spinning.

12 Ibid.

13W. Jaeger. Paidiea: The Ideals of Greek Culture, Vol. III, Oxford Press, New York, 1944. 
All this had been planned by God and nature, who destined men and women for different work. ${ }^{14}$ women, being timid, were better fitted for safeguarding the crops, while men, who were courageous, were needed when faults or failures occurred in the work done in the fields. The care and love of new-born children was innate in women. Men could more easily bear heat and cold, making long arduous journies, and take arms to defend his home ground. It was the wife who allotted each of the servants the work to be done and saw to it that it was carried out. She also looked after the food and was the doctor for anyone who was ill. She taught all household tasks to new and inexperienced maids. She was also instructed in methods to preserve her own health and beauty. Contrary to the powders and makeup of the city woman, the country wife was taught to acquire a supple body which she could achieve from the constant exercise of her work. ${ }^{15}$

The legal foundation for sexual discrimination was adopted in England and America as late as 1765 with the publication of Sir William Blackstone's Commentaries, a misrepresentation of English Common Law that held sway over

${ }^{14}$ L.A. Post, The Vatican Plato and Its Relations, Middletown, New York, 1934.

15W. Jaeger, Paideia: The Ideals of Greek Culture, Vol. III, Oxford press, New York, 1944. 
the courts for more than a century and created a psychological climate that has persisted well into our era. ${ }^{16}$

Blackstone's Commentaries stated that:

Married women were legally declared non-persons. By marriage, the husband and wife are one person in-law: that is, the legal existence of the woman is suspended during marriage, or at least is incorporated and consolidated into that of the husband under $7_{\text {whose wing }}$ and protection she performs everything. 17

Blackstone's Commentaries were the standard text books for attorneys on the legal circuit in the United States through the mid-1800's.

Psychology

There are major psychological interpretations which view women as subordinate to men. ${ }^{18}$

The sociologist, Max Weber's classical approach of the virtues of bureaucracy's exclusion of passion converges interestingly with Freud's argument that women, "the bearer of passion and equality," must be excluded from the workday world of men. 19 weber analyzed the bureaucratic structure and arrived at five characteristics. 20 These are:

${ }^{16} \mathrm{M}$. R. Beard, Women as Force in History, (Canada: MacMillan Publishing Co., 1973).

$17 \mathrm{~W}$. Blackstone, Commentaries on the Laws of England. (Boston, Beacon Press, 1962).

${ }^{18}$ M.F. Fogarty, R. Rapaport and R. Rapaport, Sex, Career and Family, etc.

${ }^{19}$ R. Kantar, Men and Women of the Corporation. (New York, Basic Books, Inc.

${ }^{20}$ D. Light and S. Keller, Sociology (New York, Alfred A. Knopf, 1975). 
1. Specialization. Bureaucratic organization is based on the belief that production should be divided into small tasks and people should specialize in one of these tasks. Considering the impossibility of one person learning every step about the construction of an airplane or all there is to know today about medicine, the reasoning behind this belief is obvious. Specialization is more efficient than generalization.

2. A hierarchy of offices. Each person is responsible to the person directly above him or her in the hierarchy and responsible for the actions of those who work under him or her.

3. Rules and regulations. Activities and relationships among officers in a bureaucracy are governed by explicit rules and regulations. In this way, each employee knows what is required of him and how his decisions will be carried out. In this way, the workings of even the most complex bureaucracy are orderly and predictable.

4. Impartiality. Personal emotions impede efficiency and therefore have no place in a bureaucracy. This is the key characteristic relating to the topic being discussed.

5. Technical competence. Positions in the bureaucracy are awarded on the basis of technical qualifications and people are paid for their work. People must be guaranteed a place, so long as they perform their official duties adequately. ${ }^{21}$

In Civilization and Its Discontents, first published in 1930, Freud wrote that women were driven by emotion and were incapable of suppressing or sublimating their passions as men could. 22

${ }^{21}$ Ibid.

${ }^{22}$ s. Freud, Civilization and Its Discontents. (New York: Norton Press, 1963). 
As an extension to this theory, Freud further stated:

That since the work of men in civilized socities removed them from their homes and families, women became hostile to the male world of organizations, constantly trying to lure men away from their higher reasoned pursuits. Economic necessity made it necessary for men to withdraw energy sexually to establish organizations in which the irrational instincts were sublimated. Organic repression paved the way to civilization, despite the costs to individuals. 23

After his early forties, Freud refrained from sexual relations with his wife, feeling this activity took energy away from his pursuit of knowledge. He theorized that by resisting female enticements, men were able to carry on the burdens of government and rational thought; rationality is the male principle in opposition to the female principle of emotionality. 24

By understanding Weber's view of the ideal bureaucracy tied in with Freud's theories of rationality and emotionality, we can further comprehend the managerial climate which carries over into today's economic market. Religion

Religion has done its share to separate men's and women's roles. The Catholic Church excludes women from priesthood and participation in its choirs. Orthodox

$$
{ }^{23} \text { Ibid. }
$$


and Conservative Judaism do not allow women to become rabbis or participate in the reading of the Torah. In the Orthodox service, women are separated from men and must sit with their own sex.

The traditional view of the various Protestant sects are essentially more liberal, but the religious leaders are still traditionally and overwhelmingly men. Politics

Varying international political systems have also had an impact on the consideration of women and equality in work possibilities. These include:

1. Fascism and communism--which theoretically afford women complete equality with men.

2. Traditional patriarchal societies in which the women's role is restricted to child bearing.

3. Democracy, in which women theoretically have the right to choose their own way of life. ${ }^{25}$

In the democratic United States, the first period of political activity for women began in 1848 when they organized for wholesale for wholesale reform in the interest of "sex equality." 26

${ }^{25}$ M. R. Beard, Women as Force in History (Canada and New York, MacMilian Publishing Company, 1973).

${ }^{26} \mathrm{~J}$. Papachristou, Women Together, (New York: Alfred A. Knopf Publisher, 1976). 
This movement started at Seneca Falls, New York, when the first women's rights convention was held. This gathering was the first of its kind in history and its speeches and discussions held an audience of 300 people for two days. Finally, they agreed unanimously to approve a Declaration of Sentiments which had been prepared earlier by the organizers of the meeting.

The Declaration paraphrased the Declaration of Independence and asserted that "all men and women are created equal." 27 It also drew up a list of charges against men who had deprived women of their rights, opportunities, and even self-respect. One of the points is as follows:

He has monopolized nearly all the profitable employments, and from those she is permitted to follow, she receives but scanty remuneration. He closes against her all the avenues to wealth and distinction which he considers most honorable to himself. As a teacher of theology, medicine, or law, she is not known. ${ }^{28}$

Another point mentioned is, "He has endeavored, in every way that he could, to destroy her confidence in her own powers, to lessen her self-respect, and to make her willing to lead a dependent and abject life." 29

The convention also adopted a set of resolutions, calling for an end to women's social inferiority, for changes in the laws that oppressed them, for educational opportunities,

\section{Ibid. \\ ${ }^{28}$ Ibid. \\ ${ }^{29}$ Ibid.}


for the end to the double standard for behavior, and for the franchise. The demand for the vote was considered the most radical and provoked heated debate.

In the second period, women achieved the right to vote. This period began in the 1890's and stretched through the 1920's. The National American Woman Suffrage. Association was founded in 1890 and this dedicated group of women were unrelenting until they reached their goal on August 26, 1920, when the Nineteenth Amendment was ratified by all the states and proclaimed part of the Constitution.

The contemporary phase began in the late 1960's. The leaders of the contemporary movement had their origin in the Civil Rights and New Left activities.

Initially, the reform spirit centered on the large number of Black Americans who suffered economic and political deprivation in a land of plenty and democracy. But, attention spread quickly to other underprivileged groups within the nation. This reform era was unusual in many ways. People were actively involved who normally were inarticulate and politically subdued. From the beginning, women were involved in these reform activities. White and Black women enlisted in the gamut of civil rights protests, from carefully devided nonviolent strategies against segregation to militant and revolutionary demands for Black power. Young women joined political groups on college campuses, including the most militant and radical. 
Older women spearheaded the call for disarmament and formed a significant part of the peace movement, which soon attracted younger women as well.

From their experience in reform activities, these women, like abolitionist women in the Nineteenth Century, learned about their own deprivation and inequality. From their concern with the needs of others, they turned to face their own. 30

In 1961, President John F. Kennedy agreed to a federal study of the status of women in the United States. The Commission on the Status of Women set about to investigate the "prejudice and outmoded customs that act as barriers to the full realization of women's basic rights. ${ }^{31}$ This was the first comprehensive investigation ever made of the status of women in the United States and it confirmed with statistical clarity that women, like minority groups, suffered discrimination and injustice. The report was published in 1963. Although its demands were moderate compared with the demands that women would soon make for themselves, it represented a major innovation ingovernment policy and attitude.

30

Ibid.

${ }^{31}$ Executive Order 10980, Establishing the President's Commission on the Status of Women, Report of the President's Commission on the Status of Women, 1963 (Washington, D.C., U.S. Government Printing Office, 1963), p. 76. 
The Commission stated:

Women in employment should have equal opportunity in hiring, training, and promotion. This should be the governing principle in private employment. An executive order should state this principle and advance its application to work done under Federal contract...32

Three important reforms expressed the general spirit of change and reaction against discrimination that permeated the early $1960^{\prime} \mathrm{s}$. They predated the emergence of the women's movement and although only one of the measures was directly concerned with women, all three would become important tools when the woman's movement began its battle against sex discrimination. The three reforms were the 1963 Equal Pay Act, the 1964 Civil Rights Act, Title VII, which made discrimination because of race, color, religion, sex, or national origin unlawful, and the third was the Executive order 11246 which prohibited the federal government and federal contractors and subcontractors from discrimination on the basis of race, color, religion, sex, or national origin.

All of these helped to pave the way for the approval of the Equal Rights Amendment by both the Senate and the House of Representatives in the spring of 1972, but

${ }^{32}$ Ibid. 
even so, it remains to be ratified by the necessary number of states.

One of the areas in which ERA may indirectly aid women in management roles is that of financial support. Under ERA the divorce partner with the greater financial resources or earning power, whether husband or wife, would be ordered to support the family or pay the alimony, if needed. If women legally are the breadwinners, the business world may see the necessity of their mobility to managerial roles, the age old theory being greater responsibility and greater renumeration. 33

While the ERA is still in the future, new legal avenues have opened through the Equal Employment Opportunity Commission, which has devoted a considerable amount of its time to cases involving discrimination based on sex and has had some success in getting employers to modify their employment policies and practices. The Equal Employment opportunity Commission (EEOC) has also opened jobs previously closed to women and has insisted on the elimination of unjustified wage differentials. 34

Therefore, a start has been made by the Commission to exert pressure on many employers to take corrective actions.

${ }^{33}$ U.S. News, Equal Right for Women: $A B C$ of the big fight. March 26, 1973, 74: 34-36.

${ }^{34} \mathrm{M}$. F. Fogarty, R. Rapaport, and R. Rapaport, Sex Career and Family, (London and Beverly Hills, Sage Publications, Inc., 1971). 
Most large companies and even many smaller ones have made changes in their personnel policies to avoid conflict with the law and to stay abreast of the times. 35

Today, women still remain heavily concentrated in relatively few occupations and industries: in the service fields, in clerical and sales positions, in factories as machine operators, and in the profession of teaching nursing and social work. 36

Statistics

The following statistics dramatically show the inequality of employment in the national labor force:

58 percent of the labor force are men

42 percent of the labor force are women

100 percent total

In the managerial level:

80 percent of the labor force are men

20 percent of the labor force are women

100 percent total

In high level administration where salaries exceed $\$ 25,000$ per year:

97.7 percent of the labor force are men

2.3 percent of the labor force are women

100.0 percent total

${ }^{35}$ R. Kantar, Men and Women of the Corporation, New York: Basic Books, Inc., 1977).

${ }^{36}$ M. F. Fogarty, R. Rapaport, and R. Rapaport, Sex Career and Family (London and Beverly Hills: Sage Publications, Inc., 1971). 
In understanding these figures ${ }^{37}$ we must keep in mind the fact that because more women than men work parttime, the proporation of women in the lower income brackets is increased. Statistics also indicate women are apt to receive lower pay than men for the same job and that in occupations where women predominate, the general level of pay is low, for example, housekeepers in hotels.

Lower pay for women, however, does not necessarily mean that they have less responsibility than men in the same jobs. In certain professions, a woman's relatively poor showing at the top may reflect neither unequal pay for the same job nor a true shortfall in achievement, but rather a tendency to see certain types of work in which women happen to specialize as less valuable to the consumer than they actually are. ${ }^{38}$

For whatever the reason, the facts relating to the differences in pay between men and women are as follows:

Women earn only 59 cents for every dollar men earn. The Census Bureau reports that in 1980, women in professional and technical positions had an annual median income of $\$ 13,729$ as compared with $\$ 21,295$ for men. Women managers and administrators had an annual median income of $\$ 12,225$ as compared with $\$ 23,295$ for men. And, while women have reported there are many opportunities opening up for them in many fields, few have become chief executives or have joined the senior ranks of major corporations. 39

37 Miami Herald, Business Monday, December 7, 1981. ${ }^{38}$ Ibid.

${ }^{39}$ Ibid. 
Women have not gained senior status in corporations because they are just now becoming commonplace in middle management. But, there also remains a variety of more subtle barriers that make the climb up the ladder more difficult. For example, some prospective customers are not always enthusiastic about a woman's handing their business. Also, male-female business relationships can sometimes result in innuendoes if there are social contacts between them outside the office.

In some circumstances, women also have been restricted from jobs because society has not expected women to pursue careers requiring knowledge of mathematics and/or science. ${ }^{40}$ More often, women can be found in so-called non-quantitative fields like personnel, public relations, advertising, and marketing.

Physical attractiveness, which is an advantage in nonmanagerial jobs, is a hindrance for top managerial positions. This discrimination seems to stem from interviewers' tendencies to equate "attractiveness" with "femininity." The result is that attractive (more feminine women) women are seen as less fit than unattractive women for "masculine type" jobs (such as being a manager) quite aside from the women's qualifications or talents needed for the job.

$$
40_{\text {Ibid. }}
$$


Men do not suffer from this problem. Researchers have found that attractiveness is an advantage for male applicants seeking managerial jobs. 41

Some women have succeeded in management because of their relationship to the owners of a business. They were already part of the inner circle. However, most women in business have found their management opportunities in low uncertainty, non-discretionary positions that bear the least pressure to close the circle; closer to the bottom, in more routinized functions, and in "expert" rather than decision-making roles. They are also found in those areas where less social contact and organizational communication are required, in staff roles that are administrative rather than line management, and in functions such as public relations, where they are removed from the interdependent social networks of the corporation's principal operations. Job failure on the part of the woman is attributed to lack of ability, whereas failure on the part of a man is attributed to "bad Iuck." 42

Review of Women in Management in Hospitality

Can a woman really take a place beside a man in management roles? A large number of studies have concluded that

${ }^{41}$ Dr. G. Dessler, Working It Out, Miami Herald, January 4, 1981 .

${ }^{42} R$. Kanter, Men and Women of the Corporation, (New York: Basic Books, Inc., 1977). 
neither man nor women want to work for a woman, however, women show more willingness to do so than men. ${ }^{43}$ In a 1965 survey of 1,000 male executives and 800 female executives, the Harvard Business Review found that two-thirds of the men and one-fifth of the women interviewed reported that they, themselves, would not feel comfortable working for a woman. Nine percent of the men and fifteen percent of the women thought that men felt comfortable working for women. ${ }^{4}$ Nearly 38 million women in the United States now work outside the home. Almost half the working mothers in the labor force have children under 18 years of age. From 1970 to 1975 women have absorbed 70 percent of all new jobs in our economy. 45

What do women want on the job and are they achieving their expectations particularly in hospitality? The days when women worked for "pin money" are long gone. Most need a job to pay the rent or in a great many cases, support the entire family.

Recent surveys indicate that 84 percent of the women in the labor force in 1975 supported themselves or were married to men who made less than $\$ 15,000$ a year. The need

\section{3} Ibid.

${ }^{44} \mathrm{H}$. Garlona and K. Prise, "Attitudes Toward Women in Management," Journal of Applied Psychology, February, 1977, $62: 29-33$.

45 Institutions and Volume Feeding: "What Do Women Really Want?" November 15, 1977, 103-106. 
for women to work keeps pace with the divorce rate which has doubled in the past ten years.

Women are no longer content to be in the usual waitress, housekeeping, clerical, sales, or secretarial jobs. Today's women expect more than her mother did. She wants to achieve both financial and psychological satisfaction. A meaningful job has a great effect on one's feeling of selfworth.

Although there are many indications that women are adequately represented in the hospitality industry in management, the plain truth is that this is just not so. ${ }^{46}$

Various restaurant owners agreed that their proportion of female managers has dropped over the past few years. They have also found that 65 to 70 percent of the women dropped out of management-training programs as compared to 40 to 45 percent of the men. One of the reasons for this is the 50 to 60 hour work week required of managers. The women most likely to finish the course are those who are divorced or childless.

Unfortunately, it seems that women's own attitudes too often close them off from creative, fulfilling progression up the management ladder--and leave them languishing in dead-end supervisory or Iine capacities. Men, for

${ }^{46}$ Canadian Hotel and Restaurant: "Women in Our Industry--Why Aren't They on Top of Things? Or Are They?" December, 1977, 13-16. 
the most part, begin to think from the outset of their careers how far they can hope to go, how to get there, what preliminary job they need in order to get the job after that. Similar problems for women aspiring to management have been explored in a book written by Margaret Hennig and Anne Jardin, The Managerial Woman. Among their findings are:

1. Women wait to be chosen, they work hard, then instead of aggressively pursuing a promotion, they wait to be discovered and asked to accept a promotion.

2. Women admit they are hesitant, instead of taking initiative they often wait to be told what to do.

3. Women are confused and feel conflict in their goals.

4. Women are reluctant to take risks. ${ }^{47}$

Women, themselves, must undertake much of the effort to overcome obstacles in their quest for managerial positions. In fact, the restlessness noted among many women employees may be attributable to such consciousness-raising. One food service supplier has already urged his corporation to devise programs for women. He suggests a five-step method:

47 . Hennig and A. Jardin, The Managerial Woman, (New York: Pocket Books, 1980). 
1. The people who run the business must make a personal commitment, not just respond to government pressure, in order to take advantage of the skills of female employees and to expose them to the system of decision-making.

2. Identify the women within the company who have the potential to get into the decision-making matrix. Then recruit others.

3. Put women with mentors--that is, seasoned employees who know how the system works, and who will pass on their knowledge and expertise.

4. Rotate women from job to job constructively so they can learn the whole business; i.e., financial, marketing research, transportation, and distribution.

5. Establish a system of meaningful review and feedback. 48

The number of women who enter hotel and restaurant management training schools still remains small. Women are still discriminated against even if they do manage to complete the required courses for administration. In a survey that was taken by the School of Hotel Administration, Cornell University, it was found that women graduates of the school had difficulty in obtaining jobs for which they

\footnotetext{
48 Institutions and Volume Feeding: "What Do Women
} Really Want?" November 15, 1977, 103-106. 
had been trained. They found it insulting to be asked if they could type or if they would accept a salary far below that being offered to a man applying for the same position. ${ }^{49}$ The Forecast for the Future

In the future, although the percentage of women in the work force is not expected to rise substantially, the percentage of women in supervisory, professional, managerial, and executive positions should increase dramatically. The rise in such opportunities, however, will probably not follow a steady upward course, but will proceed erratically. 50

The women who will succeed in a managerial capacity must be shrewd, realistic, and alert for the moment of opportunity. They must become aware of their self-imposed limitations with regard to assertiveness in seeking promotions and overcome their ingrained feelings of servility. They must develop the self-confidence necessary to compete. Since the business world is one of images, successful managers should give the impression of being confident of their abilities, comfortable with their associates, and sure of where they are going.

${ }^{49}$ Cornell Quarterly: "Women in the Hospitality Industry," August 1976: 40-47.

${ }^{50} \mathrm{R}$. Loring and $T$. Wills, Breakthrough: Women Into Management, (New York: Van Nostrand Reinhald Publishing Company, 1972). 
Thus, it is possible to see that, although the number of women in the top positions of the hospitality industry is small, the trend is there for the number to increase. The female manager must realize that there are thousands of years of misconceptions to overcome. However, the few who are in management today would not be there if they already had not met and overcome many obstacles and misconceptions. Upward mobility depends upon raw ambition, commitment, and the complete understanding of management principles. 


\section{Chapter 3: State of the Lodging Industry}

\section{and Future Trends}

Many hotels financed over the last five years will find themselves in trouble. But, someone else's financial troubles will provide a growth opportunity for strong economic entities, chains, and independents. "Hotel operators who know every aspect of their business and know their customers' needs will survive price competition after upheavals." 51

Higher interest rates have resulted in institutions and pension funds becoming direct investors in hotels. Therefore, the risk realities of equity may well result in recognition of good operations which are as important as the underlying real estate.

For a projection covering the next decade, there will be a 14 percent increase in elementary school children--from 30 million to 34 million so that family vacations probably will provide a significant market. 52

There are two factors, however, influencing this market: (a) effective marketing, and (b) the rate of divorce. Disposable income has been steadily increasing. ${ }^{53}$

On the negative side, however, hotels have to work in conjunction with other sectors of the industry to make

$5 I_{\text {Loding, }}$ "The State of the Industry," January, $1983,20-22$.

52 Ibid.

${ }^{53}$ Ibid. 
travel competitive with alternate leisure activities that consumer discretionary income.

Hotels will be dealing with a more demanding, sophisticated, restless clientele, who were brought up on five hours of television a day, and are accustomed to changing channels when they are bored or displeased. Also, clients of today and tomorrow are the product of an activist society, people who demonstrate, complain, or sue if they do not obtain their rights. This causes an acceleration of litigation activities which threaten the life of some hotels. Another trend is the decline of teenage and preretired markets and a sharp growth in middle-age and retired markets (see Table 1). This combination of added maturity and increased disposable income will probably result in more travel, more demands for lounges for conversation rather than for bars, greater guest expectation of more sophisticates services, a heightened awareness of true value, and decreased tendency toward spending to show off.

The indication that more people will be coming to resorts signifies a greater need for personnel to service them. Therefore, the expected increase by 23 percent of women in the work force should provide a constant pool of employment by the hotels and motels. (The proportion of women seeking work will rise from 51 percent to 57 percent in 1990. See Table 2.) 
In the current picture, in comparison to the rest of the economy, the lodging industry may be considered a high flyer in terms of conventional performance appraisal. Yet, as measured historically by occupancy over the last 20 years, lodging reached its peak in November, 1979. 54 Since that time, the decline in occupancy has become pervasive, reaching all types of properties. The general economic condition combined with the increase in rooms supply contribute to change in the scope of the industry. The forecast for 1983 is based on certain assumptions about the performance of the general economy. These assumptions are:

1. The prime interest rate will remain at 12 percent to 13 percent throughout the foreseeable future. 55

2. The Federal Reserve will continue to maintain relatively tight control over monetary policy and the growth of money supply, restricting the supply of credit. 56

3. The general performance of the economy will be sluggish with a slight improvement expected during 1983 of about 2 percent for the Gross National Product. 57

54 Lodging, "The Outlook for Lodging, 1983," January, $1983,29-32$.

55 Ibid.

56 Ibid.

57 Ibid. 
While a national forecast for the lodging industry can be approximated, regional forecasts are more relevant. Different parts of the country have had different reactions to the economic situation. The North Central region has been particularly hard hit, while other areas which rely more on service industries, have found their economies healthier. As a result, hotels in these latter locations have a two-fold reason for success: (a) proximity to the industries from which they draw their business, and (b) the residual effect of business travelers going from depressed areas to other parts of the country for conventions, meetings, and business.

Since businesses have cut back on travel, many firms are curtailing expenses by having their personnel attend conferences closer to home which results in a reduction of hotel room rentals.

In addition to businesses cutting back, tourism and foreign travel have suffered. The recession is worldwide, particularly in Europe and Latin America. Also, because the dollar is much stronger than most foreign currencies, the United States is a much more expensive place to visit for a vacation. Therefore, unless some real currency realignments take place, there will be fewer foreign visitors than in previous years. 
More specifically, in talking about south Florida trends, we can look at a general decline in occupancy as the recession moves southward. 58

The disturbance in the Overtown section of Miami, Florida, has had a direct effect on South Florida tourism. People are hesitant to visit the Miami area because they are afraid of the crime and the unrest that exists there.

The year-end statistics (1982) show that on Miami Beach, 54.5 percent of the hotel rooms were occupied.

The year before that, he figures was 60.1 percent. This is a decline of 5.6 percent, and is looking toward 10 percent.

Overall, for South Florida, hotels were down on their occupancy about five percent from their occupancy rates of last year. The year has been summed up as a disaster for all the hotel on Miami Beach. 59

The forecast is rather bleak, but experts do not see it "as bad as 1982 but only for the hotels that are aggressively marketing on a national and international scale. The others will be left out in the cold." 60

58 "Hotel Outlook Bleak for Dade," The Miami Herald, February 5, 1983, Sec. B., p. 4.

${ }^{59}$ Ibid.

60 Ibid. 
Chapter 4: Findings, Discussion and Conclusion

The sample selection was determined randomly. The hotels involved were those on the ocean side of Collins Avenue, from 193 street on the north to 44 street on the south. The geographical definitions are:

Miami Beach. All tourist facilities in the corporate limits from Government cut on the south to 87 Terrace on the north.

Surfside/Bal Harbour. All tourist facilities located within the corporate limits of both municipalities from 88 Street on the north to Baker's Haulover Cut.

Sunny Isles. All tourist facilities located from Haulover Beach north to the Broward County Line, east of Biscayne Bay and the Intracoastal.

Until November of 1982, these locations were part of a eight category listing published by the Dade County Department of Tourism. These were designated Airport, Downtown, Key Biscayne, Miami Beach, North Dade, South Dade, Sunny Isles, and Surfside/Bal Harbour. However, because of staff reduction, all surveys and research regarding tourism have been taken over by the accounting firm of Pannell, Kerr, Forster, and the categories have been reduced to four. They are now: Airport, Downtown, Suburban, and Beach. 61 None of the women knew ahead of time that they were going to be interviewed and they were very cooperative and very spontaneous in their answers. 
For the sake of privacy their names are not mentioned nor the names of the hotels or motels for which they work. The questionnaire was a simple one and was developed beforehand (see Appendix). The results were as follows:

1. Twenty-three percent of the respondents said it had been difficult for them to attain their present position. Seventy-seven percent said it had not been difficult for them. The majority of the women had worked their way up from other positions such as clerks and secretaries.

The consensus of those having difficulty was that "it was a man's world" and they (the women) were fortunate to be where they were today.

2. Fourteen percent were passed over when it came time for promotions as compared to 86 percent who were not. The 86 percent respondents said that they did not experience any problems moving up the ladder. They worked hard and were recognized for their abilities.

3. Seventy-seven percent responded "yes" to this question. The managers all felt that they had even more responsibility and were a vital part of their business' operative success. The women working for smaller private hotels and motels very often had more work simply because of the latitude allowed in an operation that did not have to follow strict corporate guidelines and job descriptions. 
Very often, there was an overlapping of duties because there simply was not a sufficient number of employees.

4. Seventy percent of the managers did not feel they were paid enough for their work. However, this is not because they are female, but because of the fact that the hotel business just does not pay very much. Also, the economy is bad and the hotel business is down. Therefore, raises are fewer as was previously discussed in Chapter 3. One respondent did say that she believed the salaries were different because of sex. She told this researcher that she had worked with her husband for one particular motel for 15 years and when it became necessary for her husband to leave, she was in line for his position. She was given his position along with a $\$ 60.00$ reduction in salary. She had a Business Administration degree, was trained in accounting, and was a forecasting expert. She also was able to do secretarial work. She was the highest paid female in the organization, but was later passed over for salary promotion and told that she earned more than anyone else in the office and they would not be able to increase her wages. She no longer works for the operation, but is now associated with another one, also on the Beach. This was the only tale of discrimination encountered after speaking with the 30 women. 
One woman, who works for a large chain, did say that she had been trying to persuade higher management to raise the entry salaries for a number of years, but they would not. The salaries were the same for men and women entering their trainee program.

5. Eighty percent of the women replied they were taken seriously by the public as a person in an executive capacity. If any room reservation discrepancies arose, they had the final word without having to consult anyone else. Twenty percent responded that they had had incidents where they were not taken seriously and they had to seek assistance from higher management (see Appendix).

Although this researcher did not include as part of the question whether or not the managers were treated fairly by higher management, overall the women volunteered the information and said that they were. Discussion

From the figures obtained, it is possible to see that the women interviewed, who are working as reservation managers on Miami Beach, feel that they are, for the most part, treated fairly. Therefore, it becomes apparent that these women do not feel discriminated against. They are vital links in the chain that make up successful lodging operations and they are proud of the fact that they do have the authority and the responsibilities which go along with 
this particular job. They do not envision themselves as feminists trying desperately to obtain equality. They work hard and are proud to be associated with the Hospitality Industry .

Therefore, the original hypothesis as declared by the researcher has been found to be not true and is null. 


\section{Bibliography}

Barker, E. Plato's Republic and Greek Political Theory. London, 1925.

Beard, M. R. Women as Force in History. Canada and New York: MacMillan Publishing Company, 1973.

Blackstone, W. Commentaries on the Laws of England. Boston: Beacon Press, 1962.

Boyes, M. and Newton, P. "Women in Authority: a sociopsychological analysis." Journal of Applied Psychology, 14, 17-225, 1971.

Canadian Hotel and Restaurant. Women in Our Industry--Why Aren't They on Top of Things? Or Are They? December, $1977,13-16$.

Cornell Quarterly. Examining the 80's. November, 1981. $32-36$.

Cornell Quarterly. Women in the Hospitality Industry. August, 1976, 40-47.

Dessler, Dr. G. "Working it Out." Miami Herald. January 4, 1982 .

Dun's Review. A New Era for the Hotel Industry. March, 1981, 98-102.

Fogarty, M. F., Rapaport, R., and Rapaport, R. Sex, Career and Family. London and Beverly Hills: Sage Publications, Inc., 1971.

Freud, S. Civilization and Its Discontents. New York: Norton Press, 1963.

Fulmer, R. The New Management. New York: MacMillan Publishing Company, 1978 .

Garlona, H. and Prise, K. "Attitudes Toward Women in Management." Journal of Applied Psychology, 62, 29$33,1977$.

Hennig, M. and Jardin, A. The Managerial Woman. New York: Pocket Books, Inc., 1980. 
Institutions and Volume Feeding. What do Women Really Want? November 15, 1977.

Jaeger, W. Paideia: The Ideals of Greek Culture. Vol. I, Vol. II, Vol. III. New York: Oxford University, 1943 .

Kantar, R. Men and Women of the Corporation. New York: Basic Books, Inc., 1977.

Kottak, C. Cultural Anthropology. New York: Random House, 1975.

Life Nature Library. Early Man. New York, 1972.

Light, D. and Keller, S. Sociology. New York: Alfred Al Knopf, 1975.

Lodging. The State of the Industry. January, 1983, 20-22.

Lodging. The Outlook for Lodging, 1983. January, 1983, 29-32.

Loring, R. and Wills, T. Breakthrough: Women into Management. New York: Von Nostrand Publishing Company, 1972 .

Marriott Hotels, Inc. Job Description for Reservations Managers.

Metropolitan Dade County, Department of Tourism. Research Division. Occupancy and Hotel/Motel Business Report, November, 1982.

Miami Herald, Business Monday, December 7, 1981.

Miami Herald, Business News, February 5, 1983.

Mednick, M. et al. Women and Achievement. Washington and London, Hemisphere Publishing, 1975.

Nation's Business. Lodging: Hotel Chains are Building More Room at the Inn. June, 1979, 76-79.

Pannell, Kerr, Forster. Trends in the Hotel Industry, 1982 .

Papachristou, J. Women Together. New York: Alfred A. Knopf Publisher, 1976. 
Post, L.A. The Vatican Plato and Its Relations. New York: Middletown, 1934 .

President's Commission on Status of Women. Report on Status of Women. U.S. Government Printing Office, Washington, D.C., 1963.

Smuts, R. Women and Work in America. Schoken Publishers, 1971.

Stoner, J. The New Management. Englewood Cliffs, New Jersey: Prentice Hall, 1978.

U.S. News. Equal Rights for women: $A B C$ of the Big Fight. March 26, 1973.

United States Department of Labor, Wage and Hour Division. Exemptions Under the Fair Labor Standards Act, Regulations Bulletin \#1363, August, 1976.

Williams, M. The Executive Women. Radnor, Pennsylvania: Chilton Book Company, 1977. 
Appendix 
Mrdian Incomes - womre us. Mru, 1980

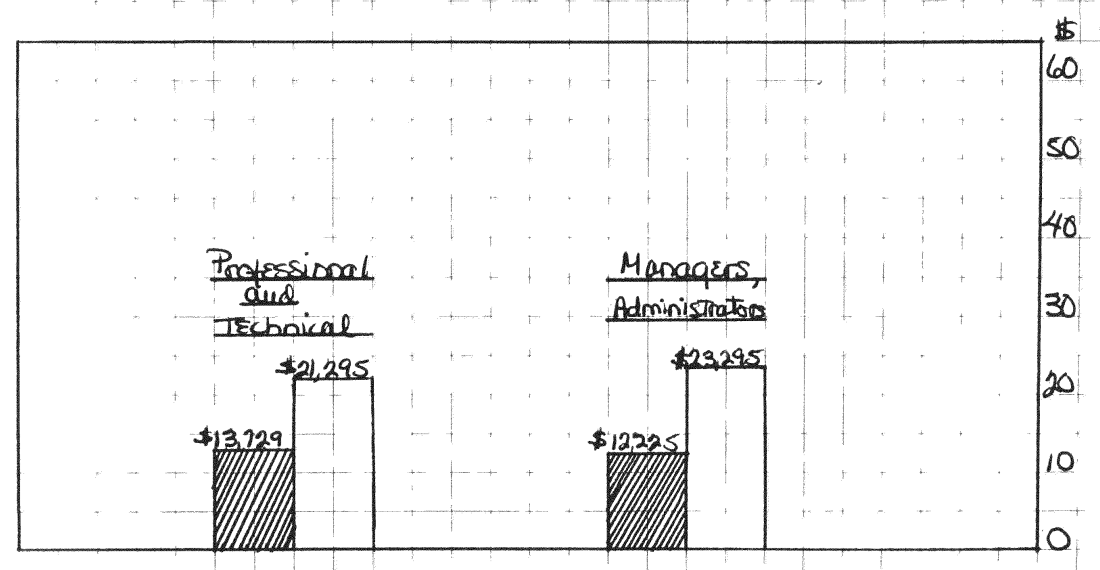

Mrs $\square$ WWomen

Source: Crnsus Buraue, United Statrs 


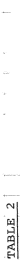

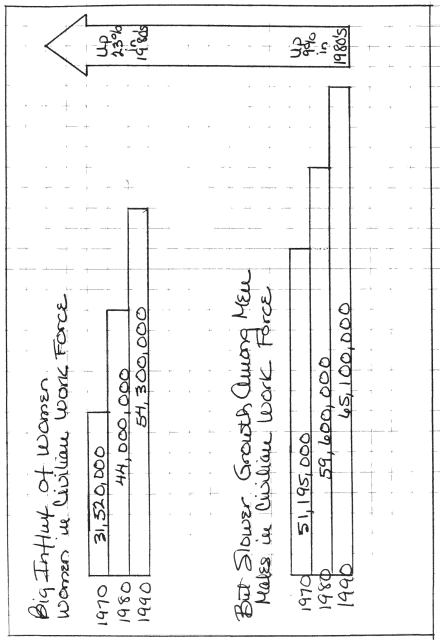

8

$\frac{1}{6}$

है

g

of 
Age Group Shifts, $1980-1990$-Projected Change in Population SEgments

TABLE 3

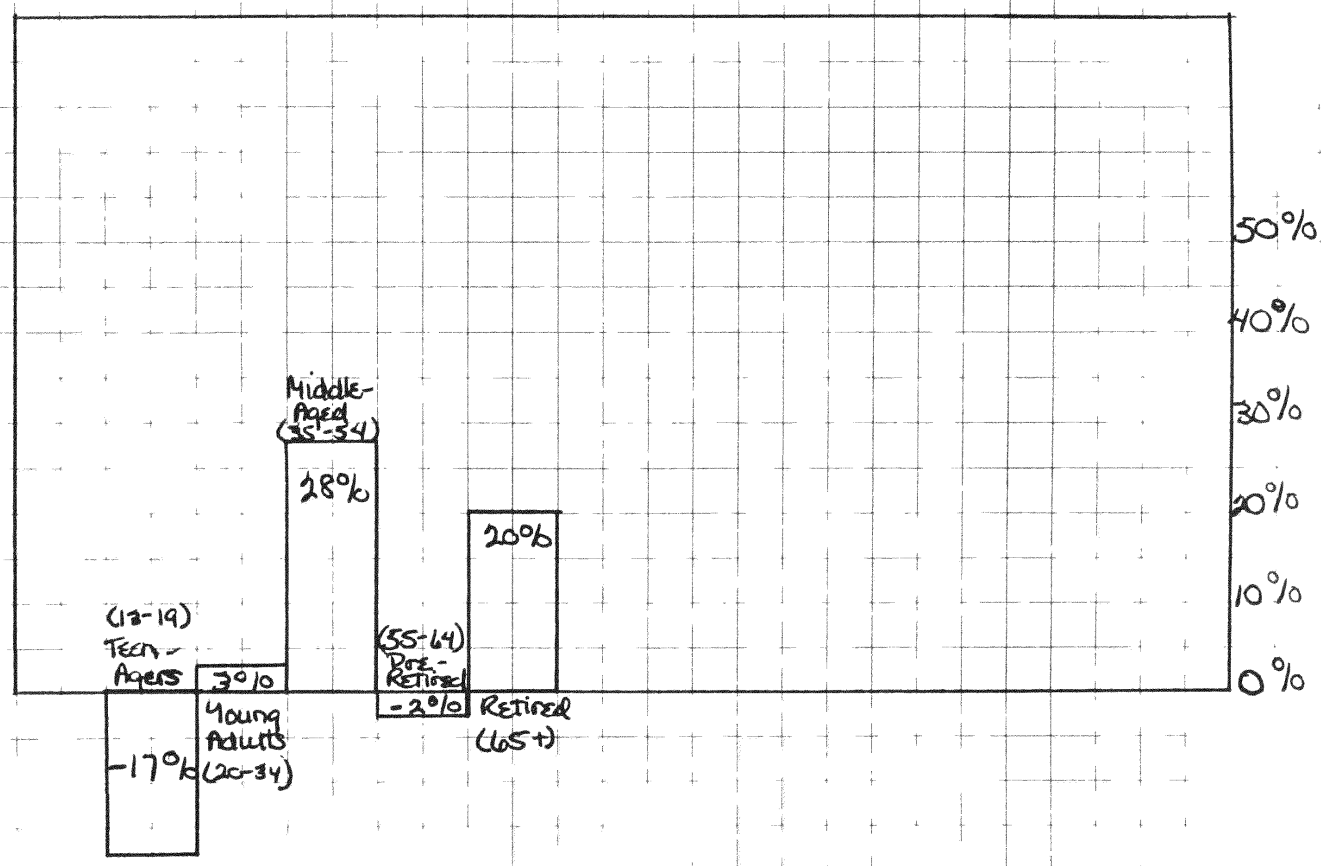

Source: United States Census Burgrave

出 

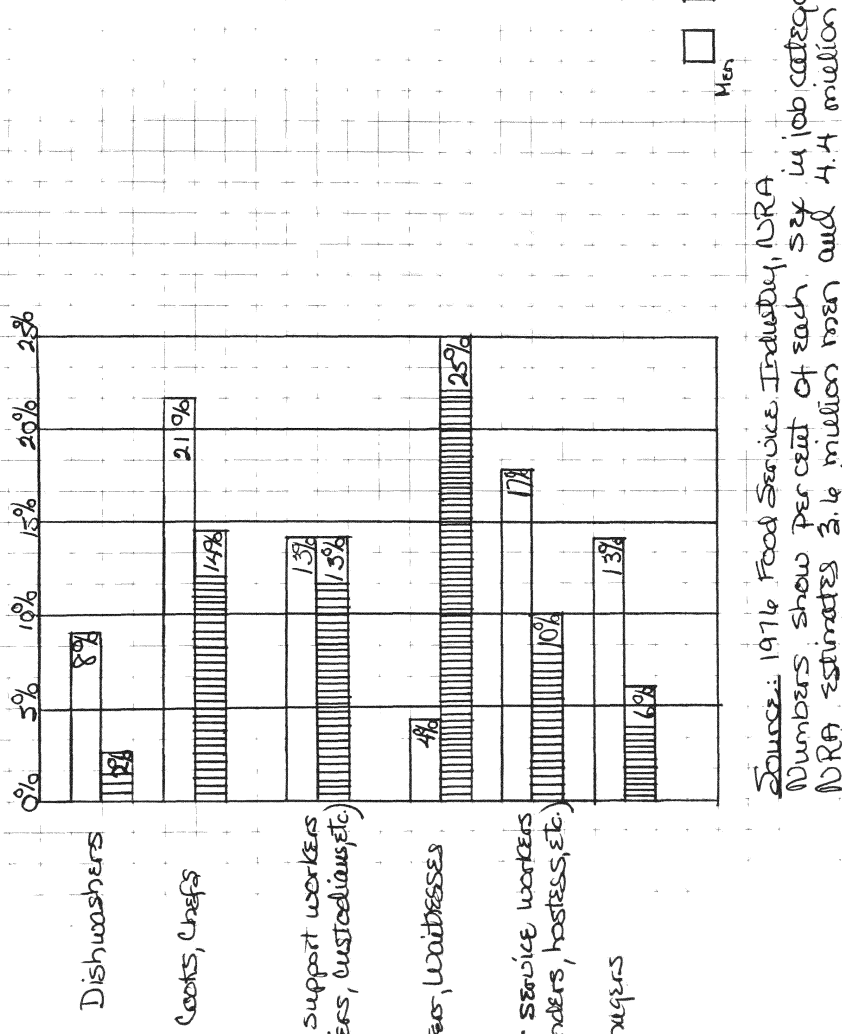

F

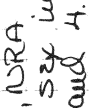

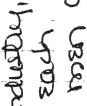

मे 8

is

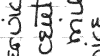

(⿻) 60 ह

\& Amin

$1130 \xi$

$\frac{1}{\pi}$ है

o .3

- n 8

.

ส

पी०23

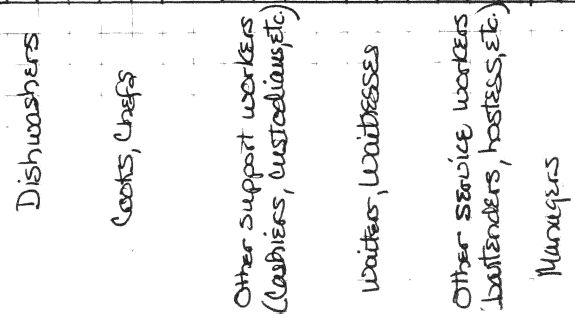


MONEY TALKS: IN HOSPITALITY MANAGEMENT, WOMEN EARN LESS THAN MEN

TABLE 5

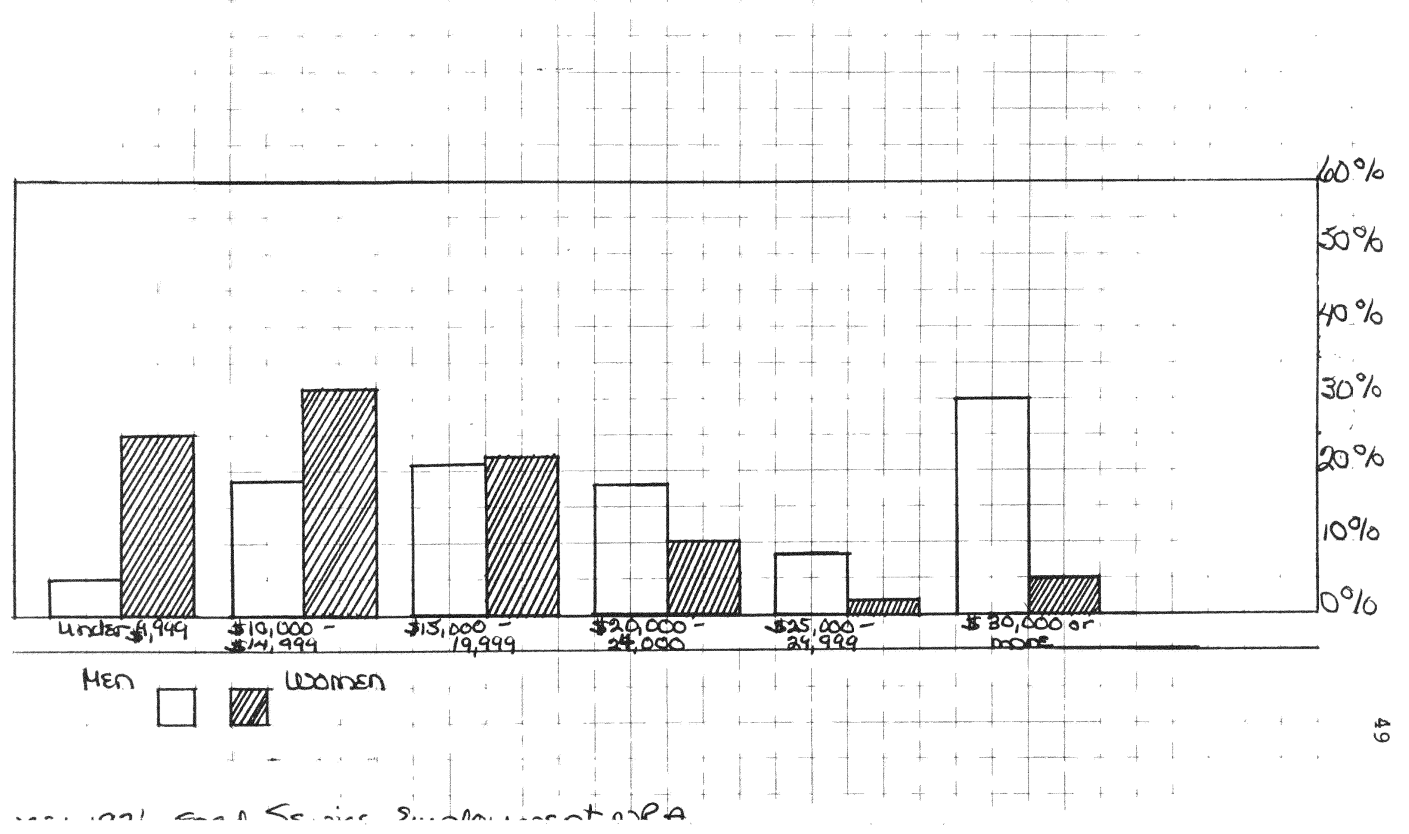




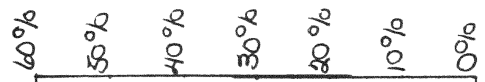

48

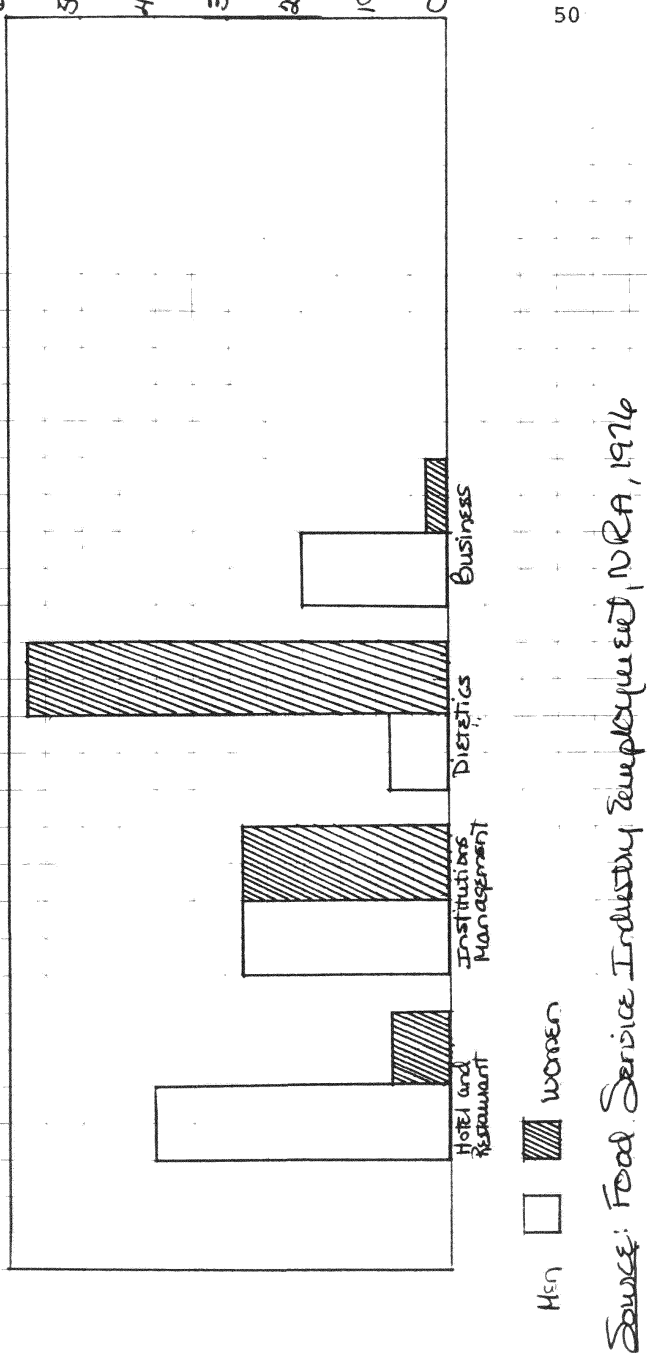


Questionnaire Submitted to Female Reservation Managers

1. Has it been difficult for you to obtain your present position?

2. Were you passed over at any time because you are a woman?

3. Are you given as much responsibility as a male counterpart?

4. Do you feel you are financially recompensed fairly for your abilities?

5. Are you taken seriously as a person in an executive capacity (to the public)? 


\section{Percentage Responses to the Questionnaire}

$$
\text { ( } 30 \text { women) }
$$

1. Has it been difficult for you to attain your present position?

$\begin{array}{ll}\text { Yes } & \text { No } \\ 23 \% & 77 \%\end{array}$

2. Were you passed over at any time because you are a women

$\begin{array}{ll}\text { Yes } & \text { No } \\ 14 \% & 86 \%\end{array}$

3. Are you given as much responsibility as a male counterpart?

$\begin{array}{ll}\text { Yes } & \text { No } \\ 77 \% & 23 \%\end{array}$

4. Do you feel you are financially recompensed fairly for your abilities?

$\begin{array}{ll}\text { Yes } & \text { No } \\ 30 \% & 70 \%\end{array}$

5. Are you taken seriously as a person in an executive capacity (to the public)?

$\begin{array}{ll}\text { Yes } & \text { No } \\ 748 & 26 \%\end{array}$


The percentage of privately owned hotels and motels versus the number of chain owned ( 30 hotels and motels).

77 percent privately owned

23 percent chain owned 
Table 8

Women's Quest for Equality Emerges in the Twentieth Century

$100 \%$ Participation in work force

90

80

10

60

so

40

30

20

10

15,000 B.C.

Line would be

8000 inches long

if to scale

Line mould be 28 inches long

if to scale
428 of work force - women

ERA passed, not ratified

Status of Women Commission

Women's Movement

'Civil Rights

\section{Right to vote}

\section{Demands for vote}

-Women's Convention in New York

Blackstone's Commentaries

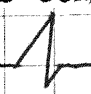

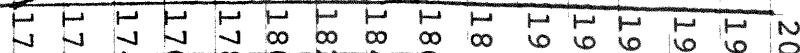

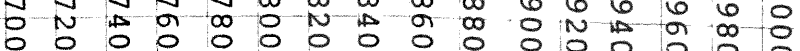

U 


\section{Vita \\ Miriam D. Goldberg}

Miriam D. Goldberg was born June 25, 1940, in

Philadelphia, Pennsylvania. Before resuming her University studies, she was active in communitive service work under the auspices of a national women's organization. She served in many executive capacities including liaison between the organization and Dade County Housing and Urban Development which, at that time, were co-sponsoring a day care center in a low-cost housing project in the Little River area.

She has taught gourmet cooking classes in the North Dade area and has taken gourmet cooking classes abroad. She is an aerobics exercise instructruess at a community cneter in the North Dade area.

The author is married to Roger D. Goldberg and they are the parents of two daughters. Lesley, age 19 and Wendy, age 14. They have been residents of North Miami Beach for 18 years. 